\title{
Dietary Intake of Vitamin D in the Czech Population: A Comparison with Dietary Reference Values, Main Food Sources Identified by a Total Diet Study
}

\author{
Svatava Bischofova ${ }^{1,2, *}$, Marcela Dofkova ${ }^{1}$, Jitka Blahova ${ }^{1}$, Radek Kavrik ${ }^{1}$, Jana Nevrla ${ }^{1}$, \\ Irena Rehurkova ${ }^{1}$ and Jiri Ruprich ${ }^{1,3}$ \\ 1 Centre for Health, Nutrition and Food, NIPH-National Institute of Public Health in Prague, 61242 Brno, \\ Czech Republic; dofkova@chpr.szu.cz (M.D.); blahova@chpr.szu.cz (J.B.); kavrik@chpr.szu.cz (R.K.); \\ nevrla@chpr.szu.cz (J.N.); rehurkova@chpr.szu.cz (I.R.); jruprich@chpr.szu.cz (J.R.) \\ 2 Department of Public Health, Faculty of Medicine, Masaryk University, 62500 Brno, Czech Republic \\ 3 Department of Milk Hygiene and Technology, Faculty of Veterinary Hygiene and Ecology, \\ University of Veterinary and Pharmaceutical Sciences, 61242 Brno, Czech Republic \\ * Correspondence: bischofova@chpr.szu.cz; Tel.: +420-515-577-511
}

Received: 20 August 2018; Accepted: 1 October 2018; Published: 7 October 2018

\begin{abstract}
The usual dietary intake of vitamin D was studied in 10 subgroups of the Czech population. Food consumption data was collected using repeated $24 \mathrm{~h}$ recall in a national cross-sectional survey (the Study of Individual Food Consumption, SISP04), and the vitamin D content in marketed foods was quantified within the national Total Diet Study (2014-2015). The Monte Carlo Risk Assessment computational model (version MCRA 8.2) was used to assess usual intake. The median vitamin D intakes for the Czech population (aged 4-90 years, both genders) were within a range of $2.5-5.1 \mu \mathrm{g} /$ day. The highest median intake, excluding dietary supplements, was observed in men aged 18-64, and the lowest was observed in children aged 4-6 and girls aged 11-17. The main sources in the diet were hen eggs (21-28\% of usual dietary intake), fine bakery wares (11-19\%), cow's milk and dairy products $(7-23 \%)$, meat and meat products $(4-12 \%)$, fish $(6-20 \%)$, and margarines (7-18\%). The dietary intake of vitamin D for more than $95 \%$ of the Czech population was below the recommended Dietary Reference Values (DRVs). These findings should encourage public health authorities to support interventions and education and implement new regulatory measures for improving intake.
\end{abstract}

Keywords: vitamin D; dietary intake; Czech population; micronutrient adequacy; dietary sources; total diet study

\section{Introduction}

Vitamin D deficiency is recognized as a global health problem at the level of all population subgroups [1]. It is associated not only with weak musculoskeletal health (e.g., rickets in children, osteopenia, osteoporosis and fractures in adults etc.), but also with increased risk of other illnesses (e.g., common cancers, autoimmune diseases, hypertension, infectious diseases, and some neuropsychological diseases) [2]. Vitamin D receptors are situated in almost every cell and tissue, evidencing its important role in many body systems (the immune, cardiovascular, and nervous systems etc.). There are two main forms of vitamin $\mathrm{D}$ : vitamin $\mathrm{D}_{3}$ (referred as cholecalciferol) and vitamin $\mathrm{D}_{2}$ (referred as ergocalciferol). For human beings, vitamin $\mathrm{D}_{3}$ is synthesized endogenously in the skin during ultraviolet $B(U V B)$ exposure or through diet, whereas vitamin $D_{2}$ is delivered only through the diet. 
Endogenous synthesis may be the main source of vitamin D, but it is influenced by many factors (latitude, season, time of day, ozone layer, air pollution, clouds, surface, time spent outdoors, use of sunscreen, clothing, skin color, age, overweight/obese status, health conditions, and others) [3]. Vitamin D synthesis ceases between October and March in the Northern Hemisphere at latitudes greater than $40^{\circ}$ north. Since the Czech Republic is situated at a latitude of around $50^{\circ}$ north, dietary intake becomes an essential source, at least during the winter season [1].

Vitamin D is naturally present in a limited number of foods, but fortified foods or dietary supplements could be also good dietary sources. The high content of vitamin D is typical for fatty fish (0.7-19 $\mu \mathrm{g} / 100 \mathrm{~g})$, because fish accumulates provitamins of vitamin $\mathrm{D}$, vitamin $\mathrm{D}_{2}$ and $\mathrm{D}_{3}$, from phytoplankton and zooplankton. Egg yolks are also good dietary source. The vitamin D content in egg yolk depends mostly on the composition of hen feed and reaches up to $12.6 \mu \mathrm{g} / 100 \mathrm{~g}$ [4]. Other animal sources of vitamin $\mathrm{D}_{3}$ are liver, meat and meat products, and milk and dairy products. Mushrooms can also be a source of vitamin $\mathrm{D}$. Vitamin $\mathrm{D}_{2}$ is produced on UVB exposure of the precursor vitamin $\mathrm{D}_{2}$ (ergosterol). Vitamin $\mathrm{D}_{2}$ content ranges from 1 to $30 \mu \mathrm{g}$ per $100 \mathrm{~g}$ fresh weight in wild mushrooms [5]. Cultivated mushrooms produced indoors do not contain vitamin D without UVB irradiation. New pure yeast or bread (containing ergosterol) treated with UVB light may be also a source.

Due to the pleiotropic effects of vitamin D in organisms as investigated over the last 20 years, Dietary Reference Values (DRVs) for dietary intake have been revaluated recently. The United States Institute of Medicine (IoM US) updated DRVs for vitamin D in 2011. The Estimated Average Requirement (EAR) was set for individuals aged one year and over at $10 \mu \mathrm{g} /$ day and the Recommended Dietary Allowance (RDA) was set at $15 \mu \mathrm{g} /$ day for those aged 1-70 years and $20 \mu \mathrm{g} /$ day for those aged 71 years and older, based on conditions of minimal sun exposure [6]. Even these increased DRVs are considered too low [7]. The European Food Safety Authority (EFSA, 2016) set an Adequate Intake (AI) of vitamin D at $15 \mu \mathrm{g} /$ day for individuals aged one year and older under conditions of assumed minimal cutaneous vitamin D synthesis [3]. The German-speaking countries (DACH 2015: Deutschland, Austria, Confoederatio Helvetica) neighboring the Czech Republic set the AI of vitamin D for people aged one year and over at $20 \mu \mathrm{g} /$ day in the case of lack of endogenous synthesis [8].

Since there has been an absence of new up-to-date data on vitamin D content in foods marketed in the Czech Republic, relevant intakes and dietary sources in different population groups remain unknown. However, this information is necessary for understanding the situation in the country and for proper decision-making by public health authorities. Thus, it was decided to include vitamin D into the ongoing national Total Diet Study (TDS) because it is widely recognized as an effective and adequately efficient tool to gain reliable data on the occurrence of chemical substances across diet and to estimate dietary exposure or intake in a population [9]. The aim of this article is therefore to describe the usual dietary intake of vitamin D in 10 Czech population groups (aged 4-90 years) based on currently measured vitamin D content in marketed foods within the national TDS, in order to compare results with available DRVs and to define the main exposure sources of vitamin D in the habitual diet of the Czech population.

\section{Materials and Methods}

The TDS method combines individual food consumption data with directly measured concentrations of vitamin D in pooled staple foods representing habitual diets. The TDS was followed by modeling of exposure doses to estimate dietary intake and identification of staple food contributors.

\subsection{Data on Food Consumption}

The food consumption data used for evaluation of vitamin D intake originated from the most recent national cross-sectional dietary survey (the Study of Individual Food Consumption, SISP04) performed in the Czech Republic over 2003-2004. The SISP04 was carried out using repeated $24 \mathrm{~h}$ diet recall with an age- and gender-representative sample of the Czech population. The used methodology respected recommendations for conducting a national dietary survey [10]. The sample was selected by 
multistage sampling combining random and quota selection. The National Population and Housing Census in 2001 served as the sampling frame. Institutionalized, homeless people and people speaking languages other than Czech or Slovak $(<4 \%)$ were not included. Two nonconsecutive $24 \mathrm{~h}$ recalls were obtained from each participant through face-to-face interviews conducted by trained interviewers in participants' households. Children below the age of 15 were interviewed in the presence of parents and small children with parental assistance. The time span between both interviews was from one to six months. Data on consumption were collected during the whole year to reduce the influence of seasonality in food consumption. All days of the week were covered by the sampling calendar. To quantify amounts of consumed food, a picture book and household measures were used. Meals were decomposed into ingredients according to individual or standard recipes. The SISP04 includes the data on food consumption from 2590 individuals (males and females aged 4-90 years, see Table 1). The overall response rate was $54 \%$. To check the quality of collected data the Goldberg/Black equation was applied for evaluation of reported energy intakes at the individual level [11]. More details on SISP04 methodology and specific data on food consumption can be found elsewhere [12-14]. Data on consumption from two nonconsecutive days were used for estimation of usual (habitual) vitamin D distribution in population subgroups. Two nonconsecutive days are sufficient for this purpose when combined with statistical modeling $[15,16]$.

Table 1. Characteristics of studied Czech population groups.

\begin{tabular}{ccccc}
\hline Sex/Age Category & $\begin{array}{c}\text { Number of } \\
\text { Subjects }\end{array}$ & $\begin{array}{c}\text { Characteristics of Age Groups } \\
\text { According to Percentiles } \\
\text { 25th-Mean-75th }\end{array}$ & $\begin{array}{c}\text { Mean Body } \\
\text { Weight (kg) }\end{array}$ & $\begin{array}{c}\text { Mean Energy Intake } \\
\text { (kcal·day } \\
\text { Including Misreporters) }\end{array}$ \\
\hline (Data \\
Children, 4-6 years & 196 & $4.0-5.1-5.4$ & 21.3 & 1903 \\
Children, 7-10 years & 311 & $7.4-8.8-9.2$ & 32.6 & 2192 \\
Males, 11-14 years & 49 & $11.2-12.6-13.0$ & 47.8 & 2891 \\
Females, 11-14 years & 51 & $11.0-12.4-13.0$ & 46.6 & 2340 \\
Males, 15-17 years & 56 & $15.1-16.2-16.4$ & 66.2 & 3474 \\
Females, 15-17 years & 58 & $15.0-16.1-16.4$ & 55.8 & 2098 \\
Males, 18-64 years & 793 & $30.3-41.9-53.0$ & 82.6 & 3148 \\
Females, 18-64 years & 873 & $31.5-44.0-55.5$ & 69.1 & 2018 \\
Males, $\geq 65$ years & 80 & $65.7-70.9-74.3$ & 82.9 & 73.3 \\
Females, $\geq 65$ years & 123 & $66.8-71.8-75.3$ & & 2660 \\
\hline
\end{tabular}

\subsection{Data on Vitamin D Content in Foods}

The vitamin D content in foods was determined by analytical measurement as a part of the national TDS. The TDS has been conducted in the Czech Republic since 1994 and covers not only contaminants but also beneficial substances in the diet. Its methodology respects the international guidelines for implementation of a TDS [9]. Vitamin D assessment was included in the national TDS in the two-year cycle from 2014 to 2015. The TDS considers the consumer behavior model which means that sampled foods include a wide range of foods usually consumed by a population and foods are culinary treated (processing the food as for consumption) before chemical analysis. Sampling in the national TDS was based on results of the national dietary survey (SISP04) and covers more than $95 \%$ staple foods of the Czech diet. The collection of food samples for vitamin D analysis was carried out in retail shops according to a complex sampling plan in 32 different locations of the Czech Republic. The selection of shops and time of purchase (seasons) respected the consumer behavior of the Czech population regularly described in household budget surveys. In total, 132 different foods (in 12 subsamples) which represented possible sources of vitamin D in the diet according to the food compositional tables were sampled. Foods were registered, culinary treated according to standardized recipes reflecting the preferred kitchen preparation by the Czech population, and pooled into 86 pooled samples before analysis. Together, 356 pooled samples composed of 4346 individual food subsamples were analyzed, with at least four for each. To ensure the accuracy and precision of food sampling and preanalytical preparation of samples, all steps were described and documented in standard operating procedures. The detailed methodology of food sampling in the national TDS is given elsewhere [17,18]. 
The usual intake of vitamin D does not include intake from dietary supplements, only that from staple foods.

\subsection{Analytical Measurement of Vitamin D in Foods}

Liquid chromatography-mass spectrometry (LC-MS/MS) was used for the determination of seven chemical individuals of vitamin $\mathrm{D}$ and its metabolites (ergocalciferol (vitamin $\mathrm{D}_{2}$ ); 25-hydroxyergo calciferol; 1,25-dihydroxyergocalciferol; cholecalciferol (vitamin $\mathrm{D}_{3}$ ) 1 ,25 dihydroxycholecalciferol; 24,25-dihydroxycholecalciferol; and 25-hydroxycholecalciferol) in foods. The measurements were carried out in the accredited laboratory (according to the European Standard EN ISO/IEC 17 025:2005, general requirements for the competence of testing and calibration laboratories) of the Centre for Health, Nutrition and Food (National Institute of Public Health).

Culinary treated TDS samples were homogenized and stored at $-80^{\circ} \mathrm{C}$ in a deep-freezing box (for no more than three months) and defrosted at laboratory temperature before the analysis. Sample preparation was based on alkaline saponification and then extraction of the analytes into non-polar solvent (hexane). The weight of the analytical portion ranged between 0.1 and $1.0 \mathrm{~g}$ (depending on the fat content and the presumed vitamin D content). Each sample was analyzed in a triplicate.

An Agilent 1200 series liquid chromatograph (Agilent Technologies, Santa Clara, CA, USA) in tandem with a triple-quadrupole API 4000 mass spectrometer (Applied Biosystems, Foster City, CA, USA) was used for the determination of vitamin D and its metabolites in foods. Positive ion Atmospheric Pressure Chemical Ionization (APCI) was used as an ionization technique. A Kinetex PFP chromatographic column $50 \times 2.1 \mathrm{~mm}$ with a particle size of $2.6 \mu \mathrm{m}$ was used to separate the analytes. Here, $0.1 \% \mathrm{HCOOH}$ in water (solvent $\mathrm{A}$ ) and $0.1 \% \mathrm{HCOOH}$ in $\mathrm{MeOH}$ (solvent $\mathrm{B}$ ) were used as mobile phase in gradient mode. Established Multiple Reaction Monitoring (MRM) transitions of analytes of interest were as follows: vitamin $\mathrm{D}_{2}-397 / 379$; vitamin $\mathrm{D}_{3}-385 / 259 ; 25-\mathrm{OH} \mathrm{D}_{2}-413 / 355$; $25-\mathrm{OH} \mathrm{D}_{3}-401 / 365 ; 1,25-\mathrm{OH} \mathrm{D}_{2}$-429/411; 1,25-OH $\mathrm{D}_{3} \_417 / 399$; and 24,25-OH $\mathrm{D}_{3}$-417/381 [19].

The analytical method was optimized and validated. Limits of quantification (LOQ; $\mu \mathrm{g} / \mathrm{kg}$ ) were determined as follows: vitamin $\mathrm{D}_{2}-0.39$; vitamin $\mathrm{D}_{3}-0.18 ; 25-\mathrm{OH} \mathrm{D}_{2}-0.84 ; 25-\mathrm{OH} \mathrm{D}_{3}-0.97$; $1,25-\mathrm{OH} \mathrm{D}_{2}-0.69 ; 1,25-\mathrm{OH} \mathrm{D}_{3}-0.86$; and $24,25-\mathrm{OH} \mathrm{D}_{3}-0.25$. Recovery of all analytes was verified on a set of real samples representing different matrices, which were spiked by the mixture of standards of all analytes. Recovery ranged between 70 and $110 \%$ according to the matrix.

The accuracy and precision of the entire analytical procedure were controlled by using the composite internal standard containing isotopically-labeled (C13) vitamin $\mathrm{D}_{3}, 25-\mathrm{OH} \mathrm{D}_{3}$, and $1,25-\mathrm{OH}$ $\mathrm{D}_{3}$ by measuring the certified reference material SRM 1849a Infant Formula (NIST) in each series, and by successfully participating in proficiency testing (FAPAS, Food Analysis Performance Assessment Scheme, Fera Science Ltd., UK).

\subsection{Estimation of Vitamin D Usual Dietary Intake in the Czech Population}

Modeling of vitamin D dietary intake was based on individual food consumption data and TDS concentration data. The Monte Carlo Risk Assessment computational model (MCRA, version 8.2) [20] was used to estimate usual dietary intake. We applied following calculation parameters: MCRA settings for the TDS, the Logistic-Normal-Normal exposure model, and the lower bound (LB) and upper bound (UB) for intake of the sum of vitamin $\mathrm{D}_{2}+\mathrm{D}_{3}$. Lower Bound left-censored concentration values for vitamin $D_{2}$ or $D_{3}$ were replaced by 0 , and the UB were replaced by the LOQ for each analyzed food sample. The 5th, 25th, 50th, 75th, and 95th percentiles of intakes and their confidential intervals (CI p2.5 and p97.5) per person and day were calculated. Dietary intakes of vitamin D were estimated specifically for 10 Czech population groups: children (both sexes) aged 4-6 years, children (both sexes) aged 7-10 years, males aged 11-14 years, females aged 11-14 years, males aged 15-17 years, females aged 15-17 years, males aged 18-64 years, females aged 18-64 years, males aged $\geq 65$ years, and females aged $\geq 65$ years. The choice of these population groups was related to the structure of results from the national food consumption study and recommendations for vitamin D dietary intake. 


\subsection{Assessment of Vitamin D Dietary Intake}

To evaluate the adequacy, the vitamin D usual intake distributions were compared with the American EAR (IoM US 2011) and European AI (EFSA 2016, DACH 2015) reference values. The EAR cut-point method was used when comparing vitamin D usual intake with the EAR. This approach assumes that proportion of individuals with usual intake below the EAR in a group corresponds to the proportion of subjects with inadequate intake. The comparison with AI reference values can be performed qualitatively. If the median intake is above the $\mathrm{AI}$, the prevalence of inadequate intake in a population could be considered as low. However, if the median intake is below the AI, the adequacy cannot not be evaluated [6,21].

\subsection{Limitation of Study Results}

Among the limitations of the results it should be mentioned that a relatively long time had passed since the data on food consumption (SISP04) was collected. However, it is necessary to highlight that it was the most recent national-wide survey on the individual level conducted in the Czech Republic. Food consumption patterns over time seemed quite unchanged in the country based on Czech Statistical Office data comparing the years from 2006 to 2014 [22]. Moreover, the sampling in the national TDS is regularly updated based on market share data to avoid this disadvantage. Another possible source of inaccuracy is the fact that foods sampled in the national TDS represent not the whole usual Czech diet but only about $95 \%$.

\section{Results}

\subsection{Usual Dietary Intake and Its Distribution in Ten Czech Population Groups}

Usual vitamin D intakes from foods (without dietary supplements) were low in the Czech population. The median usual intakes ranged from $2.5 \mu \mathrm{g} /$ day (in children 4-6 years, in females 11-14 years, and in females 15-17 years) to $5.1 \mu \mathrm{g} /$ day (in men aged 18-64 years). When compared to the EFSA and DACH DRV, the adequacy of vitamin D intake could not be evaluated, because the values of mean intake were below the AI. However, the vitamin D intake was evaluated as inadequate in all population subgroups when compared with EARs of the Institute of Medicine [6]. The deficiency of vitamin $\mathrm{D}$ in the diet was observed in more than $95 \%$ of individuals in all evaluated population groups.

The distribution of usual dietary intakes found in TDS for the 10 Czech population groups and the comparison with DRVs (AI, EAR) are presented in Table 2.

\subsection{Food Sources of Vitamin D Intake in the Czech Population Groups}

Table 3 shows main exposure dietary sources of vitamin D in the Czech Republic as recognized by the TDS. In all population groups hen eggs, fine bakery wares (excluding biscuits), and margarines were identified among the most important sources of dietary vitamin $\mathrm{D}$. 
Table 2. Distribution of usual intake of vitamin $\mathrm{D}$ (sum of $\mathrm{D}_{2}+\mathrm{D}_{3}$ in $\mu \mathrm{g} /$ person/day) from total diet in 10 Czech population groups.

\begin{tabular}{|c|c|c|c|c|c|c|c|c|c|c|c|}
\hline \multirow{3}{*}{ Sex/Age Category } & \multirow{3}{*}{$n$} & \multicolumn{5}{|c|}{ Percentiles of Usual Intakes (LB-UB) ${ }^{(1)}$} & \multirow{2}{*}{\multicolumn{2}{|c|}{$\begin{array}{c}\text { Requirement AI (2) } \\
(\mu \mathrm{g} / \text { day })\end{array}$}} & \multirow{3}{*}{$\%$ Inadequacy ${ }^{(3)}$} & Requirement & \multirow{3}{*}{$\begin{array}{l}\% \text { of Individuals } \\
\text { Exceeding the EAR } \\
\text { (LB-UB Intakes) }^{(4)}\end{array}$} \\
\hline & & 5 & 25 & 50 & 75 & 95 & & & & & \\
\hline & & \multicolumn{5}{|c|}{ ( $\mu \mathrm{g} /$ person/day) } & $\begin{array}{c}\text { EFSA * } \\
2016\end{array}$ & $\begin{array}{c}\text { DACH * } \\
2015\end{array}$ & & $\begin{array}{c}\text { IoM US * } \\
2011\end{array}$ & \\
\hline Children, both sexes, 4-6 years & 196 & $1.6-2.2$ & $2.1-2.8$ & $2.5-3.4$ & $3.1-4.0$ & $4.0-5.1$ & 15 & 20 & ns & 10 & $0-0$ \\
\hline Children, both sexes, $7-10$ years & 311 & $1.8-2.4$ & $2.3-3.1$ & $2.7-3.7$ & $3.3-4.3$ & $4.2-5.5$ & 15 & 20 & ns & 10 & $0-0$ \\
\hline Males, $11-14$ years & 49 & $2.0-2.7$ & $3.0-3.8$ & $3.8-4.9$ & $4.9-6.2$ & $7.1-8.9$ & 15 & 20 & ns & 10 & $0.6-2.5$ \\
\hline Females, $11-14$ years & 51 & $1.2-1.7$ & $1.8-2.6$ & $2.5-3.5$ & $3.5-4.6$ & $5.6-7.0$ & 15 & 20 & ns & 10 & $0.3-0.7$ \\
\hline Males, $15-17$ years & 56 & $1.9-2.5$ & $2.8-3.7$ & $3.8-4.9$ & $5.0-6.5$ & $7.6-9.8$ & 15 & 20 & ns & 10 & $1.1-4.5$ \\
\hline Females, $15-17$ years & 58 & $1.0-1.2$ & $1.7-2.1$ & $2.5-3.1$ & $3.6-4.7$ & $6.1-8.3$ & 15 & 20 & ns & 10 & $0.5-2.5$ \\
\hline Males, $18-64$ years & 793 & $2.0-2.6$ & $3.0-3.9$ & $3.9-5.1$ & $5.2-6.7$ & $7.6-9.9$ & 15 & 20 & ns & 10 & $1.0-4.8$ \\
\hline Females, $18-64$ years & 873 & $1.4-1.9$ & $2.1-2.7$ & $2.8-3.5$ & $3.7-4.6$ & $5.6-6.7$ & 15 & 20 & ns & 10 & $0.1-0.3$ \\
\hline Males, $\geq 65$ years & 80 & $1.6-2.2$ & $2.5-3.4$ & $3.5-4.6$ & $4.7-6.2$ & $7.3-9.5$ & 15 & 20 & ns & 10 & $1.0-3.9$ \\
\hline Females, $\geq 65$ years & 123 & $2.1-2.6$ & $2.7-3.3$ & $3.1-3.9$ & $3.6-4.5$ & $4.4-5.7$ & 15 & 20 & ns & 10 & $0-0$ \\
\hline
\end{tabular}

(1) Lower bound (LB) and upper bound (UB) for the sum of vitamin $\mathrm{D}_{2}+\mathrm{D}_{3}$. ${ }^{(2)} \mathrm{An} \mathrm{AI}$ is set when scientific evidence is insufficient to set an EAR. (3) When the median intake (50th percentile) of the population is above the AI, the risk for inadequate intake is low. No statement (ns) is formulated on the adequacy of vitamin D when the median intake is below the AI. (4) Usual intake was for $>95$ th percentile individuals of all sex/age categories lower than the EAR. * All requirements are set based on conditions of minimal sun exposure (i.e., only from diet). AI: Adequate Intake; EAR: Estimated Average Requirement; EFSA: European Food Safety Authority; DACH: German-speaking countries (Deutschland, Austria, Confoederatio Helvetica); IoM: Institute of Medicine. 
Table 3. Main dietary sources of vitamin D in 10 Czech population groups.

\begin{tabular}{|c|c|c|c|c|c|}
\hline Sex/Age Category & Food & $\begin{array}{c}\text { \% Contribution to Usual } \\
\text { Dietary Intake of Vitamin D }\end{array}$ & Sex/Age Category & Food & $\begin{array}{c}\text { \% Contribution to Usual } \\
\text { Dietary Intake of Vitamin D }\end{array}$ \\
\hline \multirow{6}{*}{ Children, 4-6 years } & Hen eggs & 20.9 & \multirow{6}{*}{ Children, $7-10$ years } & Hen eggs & 21.4 \\
\hline & Fine bakery wares (excluding biscuits) & 15.3 & & Fine bakery wares (excluding biscuits) & 19.2 \\
\hline & Cow's milk & 12.5 & & Margarines & 10.4 \\
\hline & Margarines & 12.4 & & Cow's milk & 9.8 \\
\hline & Cocoa drinks powder & 5.5 & & Butter & 5.1 \\
\hline & $\sum$ & 66.6 & & $\Sigma$ & 65.9 \\
\hline \multirow{6}{*}{ Males, 11-14 years } & Hen eggs & 25.7 & \multirow{6}{*}{ Females, 11-14 years } & Hen eggs & 22.7 \\
\hline & Margarines & 15.8 & & Fine bakery wares (excluding biscuits) & 17.5 \\
\hline & Fine bakery wares (excluding biscuits) & 14.4 & & Margarines & 13.1 \\
\hline & Cow's milk & 7.7 & & Cow's milk & 8.9 \\
\hline & Butter & 5.1 & & Freshwater fish & 5.8 \\
\hline & $\Sigma$ & 68.7 & & $\Sigma$ & 68.0 \\
\hline \multirow{6}{*}{ Males, $15-17$ years } & Hen eggs & 23.8 & \multirow{6}{*}{ Females, $15-17$ years } & Hen eggs & 27.9 \\
\hline & Fine bakery wares (excluding biscuits) & 14.6 & & Fine bakery wares excluding biscuits & 12.4 \\
\hline & Margarines & 8.6 & & Margarines & 7.1 \\
\hline & Cow's milk & 5.4 & & Cow's milk & 6.4 \\
\hline & Marinated fish & 5.3 & & Smoked fish & 5.6 \\
\hline & $\sum$ & 57.7 & & $\Sigma$ & 59.4 \\
\hline \multirow{6}{*}{ Males, 18-64 years } & Hen eggs & 21.4 & \multirow{6}{*}{ Females, 18-64 years } & Hen eggs & 23.3 \\
\hline & Fine bakery wares (excluding biscuits) & 11.4 & & Fine bakery wares (excluding biscuits) & 12.3 \\
\hline & Margarines & 9.4 & & Margarines & 12.3 \\
\hline & Salads* & 6.2 & & Freshwater fish & 8,0 \\
\hline & Pork meat & 4.8 & & Salads* & 4.2 \\
\hline & $\Sigma$ & 53.2 & & $\Sigma$ & 60.1 \\
\hline \multirow{6}{*}{ Males, $\geq 65$ years } & Hen eggs & 22.6 & \multirow{6}{*}{ Females, $\geq 65$ years } & Hen eggs & 21.7 \\
\hline & Margarines & 12.7 & & Margarines & 17.6 \\
\hline & Fine bakery wares (excluding biscuits) & 12.3 & & Fine bakery wares (excluding biscuits) & 14.2 \\
\hline & Butter & 5.3 & & Freshwater fish & 9.8 \\
\hline & Marinated fish & 5.2 & & Cow's milk & 5.4 \\
\hline & $\sum$ & 58.1 & & $\Sigma$ & 68.7 \\
\hline
\end{tabular}

* Salads are composed of $50 \%$ of fish salad. 


\subsection{Vitamin D Content in Foods and Food Groups}

In total, 86 pooled types of food samples were analyzed for vitamin D content. Only two forms of vitamin $\mathrm{D}\left(\mathrm{D}_{2}\right.$ and $\left.\mathrm{D}_{3}\right)$ were detected in foods; other forms were always below the limits of detection. Vitamin $\mathrm{D}_{2}$ was detected only in low concentrations in a minority of TDS samples (e.g., in marinated fish, smoked fish, and canned meat) and therefore it probably does not play too important a role in the dietary intake of Czechs.

Figure 1 shows 20 groups of foods (TDS pooled samples) with the highest average content of vitamin $\mathrm{D}$ (sum of $\mathrm{D}_{2}+\mathrm{D}_{3}$ ) in $100 \mathrm{~g}$ of edible portions. The highest contents of vitamin $\mathrm{D}$ (sum of $\mathrm{D}_{2}+\mathrm{D}_{3}$ ) were measured in fish and fish products (smoked, marinated, freshwater, canned fish) at 5.45-11.11 $\mu \mathrm{g} / 100 \mathrm{~g}$, in milk-based infant formula powder at $9.92 \mu \mathrm{g} / 100 \mathrm{~g}$, in margarines (which are fortified foods) at $8.17 \mu \mathrm{g} / 100$, in hen eggs at $4.03 \mu \mathrm{g} / 100 \mathrm{~g}$, in salads (composed of $50 \%$ fish salad) at $2.99 \mu \mathrm{g} / 100 \mathrm{~g}$, in fermented dry salami at $1.93 \mu \mathrm{g} / 100 \mathrm{~g}$, and in hen meat at $1.73 \mu \mathrm{g} / 100 \mathrm{~g}$.

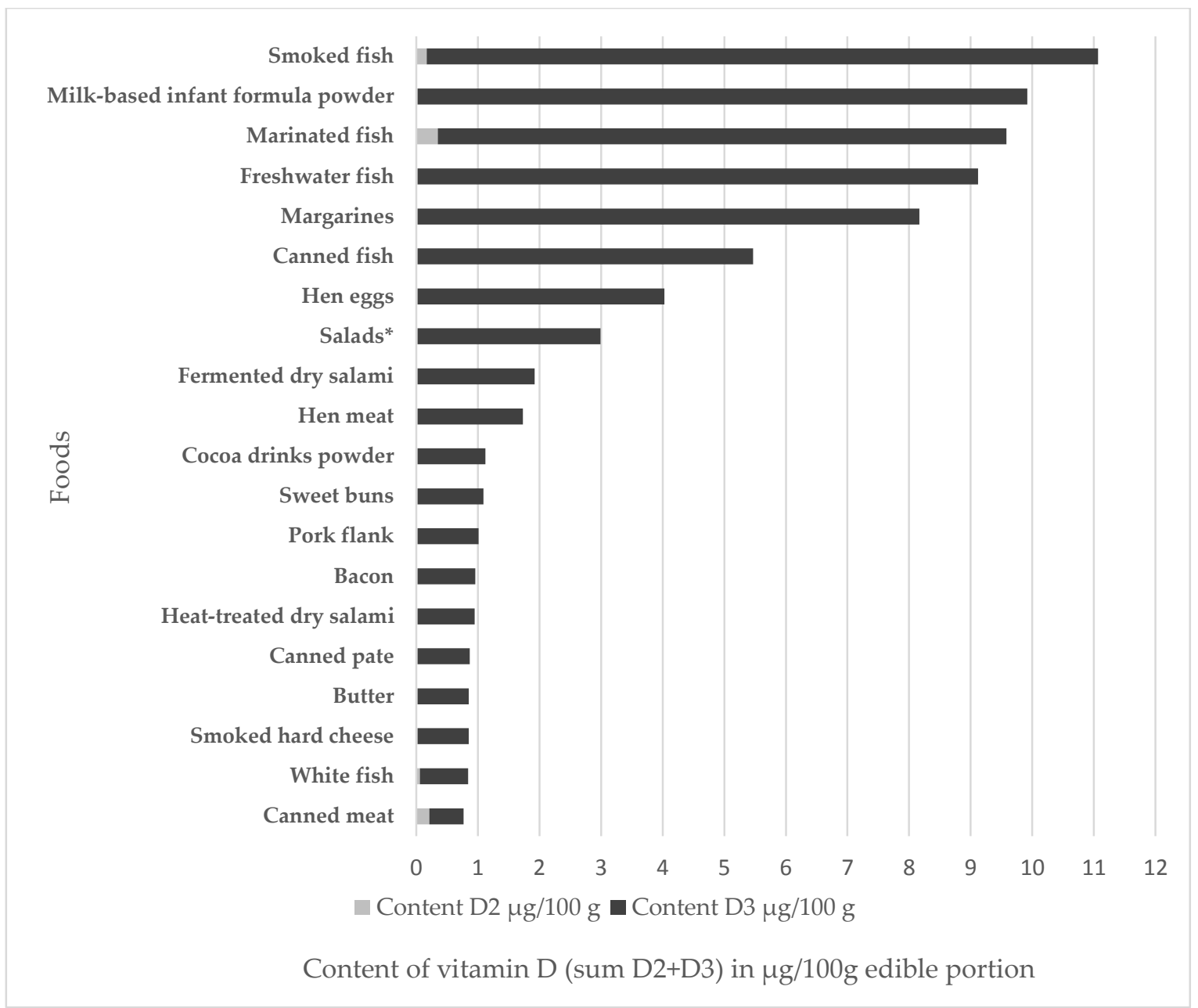

Figure 1. The 20 foods with the highest vitamin D content. * This pooled sample is for $50 \%$ fish salad.

Table 4 shows an overview of analyzed food groups and the ranges of vitamin D content. In total 86 pooled samples, which included 132 food items, were divided into 19 groups. This division is based on the recommended FoodEx2 classification [23]. 
Table 4. Overview of vitamin D content in analyzed food groups.

\begin{tabular}{|c|c|c|}
\hline Food Group & $\begin{array}{l}\text { Number }(n) \text { of Kinds of Foods } \\
\text { in a Group }\end{array}$ & $\begin{array}{l}\text { Range of Vitamin D Content (Sum } \\
\left.D_{2}+D_{3}\right) \mu g / 100 \mathrm{~g} \text { Edible Portion }\end{array}$ \\
\hline Fish and products & 5 & $0.83-11.11$ \\
\hline Milk-based infant formula powder & 1 & 9.92 \\
\hline Cocoa drink powder & 1 & 1.12 \\
\hline Chocolate and chocolate products & 2 & $<\mathrm{LOQ} *$ \\
\hline Eggs & 1 & 4.03 \\
\hline Milk and cream & 4 & $0.16-0.53$ \\
\hline Fermented milk products & 5 & $<\mathrm{LOQ}^{*}-0.62$ \\
\hline Dairy desserts & 4 & $0.07-0.71$ \\
\hline Cheese & 7 & $0.05-0.85$ \\
\hline Vegetable fats and oils & 4 & $<\mathrm{LOQ}^{*}-8.17$ \\
\hline Animal fats & 2 & $<\mathrm{LOQ}^{*}-0.85$ \\
\hline Meat and offal & 10 & $<\mathrm{LOQ}^{*}-1.73$ \\
\hline Meat products & 16 & $<\mathrm{LOQ}^{*}-1.93$ \\
\hline Cereals and flours & 4 & $<\mathrm{LOQ} *$ \\
\hline Bread and similar products & 5 & $<\mathrm{LOQ}^{*}$ \\
\hline Fine bakery products & 6 & $<\mathrm{LOQ}^{*}-1.09$ \\
\hline Pasta and doughs & 2 & $<\mathrm{LOQ}^{*}$ \\
\hline Fruit, vegetables and cultivated mushrooms & 5 & $<\mathrm{LOQ}^{*}$ \\
\hline Miscellaneous foods & 2 & $0.25-2.99$ \\
\hline
\end{tabular}

\section{Discussion}

Vitamin D in the body originates either from dietary sources or from endogenous synthesis. As mentioned previously, due to its geographical location the Czech population is to a large extent dependent on dietary intake of vitamin $\mathrm{D}$ at least during the late autumn, winter, and early spring. Moreover, some population groups can be at risk year-round (i.e., people with minimal sun exposure-e.g., individuals working indoors, homebound individuals, institutionalized people, etc.). That is why the present research was focused on describing vitamin D intake from diet. The results describe usual dietary intake of vitamin D in the Czech population, which was evaluated on the basis of individual food consumption data from the most recent national dietary survey (SISP04) and measured concentrations of vitamin D in marketed food sampled as a part of the national TDS. Such approach was more advantageous compared to the usage of Food Composition Tables (FCTs) for calculation of dietary intake because data on vitamin D content in Czech FCTs is not entirely up to date or is missing for some foods. Intake from dietary supplements is not included into presented results because only limited information on that was available in food consumption data.

It was found that median usual intakes of vitamin D from foods ranged from 2.5 to $4.9 \mu \mathrm{g} /$ day in Czech children and adolescents (aged 4-17 years) and from 2.8 to $5.1 \mu \mathrm{g} /$ day in Czech adults (aged 18-90 years). The highest dietary intake of vitamin D (9.9 $\mu \mathrm{g} /$ day, UB, 95th percentile) was observed in men aged 18-64 years.

When comparing the Czech results with those from other European countries the situation in terms of vitamin D dietary intake is similar. According to an EFSA report (2012) comparing results from 14 European countries, the mean intake without dietary supplements in children and adolescents varied from 1.4 to $4 \mu \mathrm{g} /$ day, in adult women from 1.1 to $6.0 \mu \mathrm{g} /$ day, and in adult men from 1.5 to $8.2 \mu \mathrm{g} /$ day. The highest intake from foods was identified in men from Finland ( $16 \mu \mathrm{g} / \mathrm{day}, 25-74$ years, 95th percentile) [24]. In this context it is necessary to mention that there was a large diversity in the methodologies of the described studies.

Vitamin D intake, excluding food supplements, was also explored in the EPIC (the European Prospective Investigation into Cancer and Nutrition) study (1992-1999) in 10 European countries using $24 \mathrm{~h}$ dietary recall and a standardized nutrient database. When all countries were combined, the mean vitamin D intake (the EPIC mean) was determined in adults (35-74 years) as $3.3 \mu \mathrm{g} /$ day for women and $4.8 \mu \mathrm{g} /$ day for men, and the highest level of vitamin D intake was observed in Sweden [25]. 
Viñas (2011) compared vitamin D intake in European adults (19-64 years) and the elderly ( $>64$ years) from 11 European countries. Mean daily vitamin D intakes were between 2 and $5 \mu \mathrm{g} /$ day in most investigated countries, but the highest (up to $9 \mu \mathrm{g} /$ day) was in Nordic countries (Sweden, Finland) [1,26]. Mensink et al. (2013) reanalyzed raw data from eight European national surveys (Belgium, Denmark, France, Germany, the Netherlands, Poland, Spain, and the United Kingdom). The mean intakes ranged in children and adolescents (4-17 years) from 1.5 to $4.8 \mu \mathrm{g} /$ day, and in adults from 0.8 to $6 \mu \mathrm{g} /$ day [27]. The most recent data from a Spanish study (ANIBES) showed the total mean intake of vitamin D in the population was $4.4 \pm 0.1 \mu \mathrm{g} /$ day [28], and a similar Belgian study (VITADEK) showed the mean intake of vitamin D from natural and fortified foods (without supplements) was 3.37-4.41 $\mu \mathrm{g} /$ day in men aged 3-64 years and 3.18-3.48 $\mu \mathrm{g} /$ day in women aged 3-64 years [29].

In most of the above referenced surveys the highest levels of vitamin D intake were described in Nordic countries. The difference between Nordic countries and the Czech Republic can be attributed especially to much lower fish consumption among Czech people. Moreover, a much wider range of products in Nordic countries is mandatorily fortified (milk, milk products, margarine) [1] when compared to the situation in the Czech market.

A comparison with available DRVs indicated that the dietary intake of vitamin D is too low in the majority of the Czech population ( $>95 \%)$. Unfortunately, there was only a limited possibility for comparison of the present findings with results on vitamin $\mathrm{D}$ status based on biomarker measurements such as 25 -hydroxyvitamin $\mathrm{D}(25(\mathrm{OH}) \mathrm{D})$. The main marker of vitamin $\mathrm{D}$ saturation in the body is $25(\mathrm{OH}) \mathrm{D}$, which reflects dietary intake as well as endogenous synthesis. Some data were produced as a part of the Czech biological monitoring performed by the NIPH, but its status has only been described recently in children aged 5 and 9 years (a study for adults is ongoing). In the spring about $50 \%$ of children $(n=124)$ had $25(\mathrm{OH}) \mathrm{D}$ levels lower than $50 \mathrm{nmol} / \mathrm{L}$; in summer this was the case for about $10 \%$ of children $(n=85)$, and in winter for more than $30 \%$ of children $(n=66)$ [30]. Even those these results are not extensive, they support our findings that dietary intake is low and, particularly in the winter season, it is not enough to cover vitamin D requirements.

The foods that contribute substantially to dietary intakes of vitamin D differ across countries according to habitual dietary patterns and fortification policies. In the Czech population the following main sources of vitamin D exposure were identified: hen eggs (contribution to the usual intake: $21-28 \%)$, fine bakery wares excluding biscuits (11-19\%), cow's milk and dairy products (7-23\%), fortified margarines (7-18\%), fish and fish products (6-20\%), and meat and meat products (4-12\%).

In the United Kingdom, the major dietary sources in children aged 4-10 years are milk and milk products $(13 \%)$, meat and meat dishes $(25 \%)$, fat spreads $(21 \%)$, cereal and cereal products $(20 \%)$, fish and eggs $(8 \%)$. In adults the main dietary sources of vitamin D are meat and meat products $(27 \%$ for women, $34 \%$ for men), fat spreads ( $19 \%$ for men, $20 \%$ for women), fish and fish dishes ( $15 \%$ for men, $18 \%$ for women), eggs ( $14 \%$ for men, $12 \%$ for women), cereal and cereal products ( $13 \%$ for men, $12 \%$ for women), and milk and milk products (5\% in both groups) [31]. In Irish adults, the significant contributors are meat (30\% in people aged $18-64$ years, $22 \%$ in people $\geq 65$ years), fish ( $12 \%$ in people aged $18-64$ years, $16 \%$ in people $\geq 65$ years), and spreads (10\% in people aged $18-64$ years, $13 \%$ in people $\geq 65$ years) [32]. In Denmark, in the population aged 7-39 years, the main contributors of vitamin D are fats (36\%), meat and meat products $(20 \%)$, fish and shellfish $(8 \%)$, and fine pastries (7\%) [21]. In France, fish contributes $31 \%$ of dietary vitamin D intake in children and $38 \%$ in adults. Eggs contribute $10 \%$ and $9 \%$, and cheese $9 \%$ and $7 \%$ of dietary vitamin D intake in children and adults, respectively [33]. In Spain, the situation is similar to that of France. The main source of vitamin D is fish (68\% of vitamin D intake), eggs (20\%), and cereals (4\%) [34]. In Finland, the major food sources of vitamin D are fish, dietary fats, and fortified liquid milk and dairy products. Dietary fats have been fortified with vitamin D since the 1950s and milk since 2003 [35,36]. In Norway, the most important sources of vitamin D are fatty fish, fortified fats (margarines, butter), and supplements with cod liver 
oil, a similar situation to that in Iceland. In Sweden, the main vitamin D sources are dietary fat, oil-rich fish and fish products, and fortified milk and dairy products [1,37].

As we can see, fatty fish are an important source of vitamin D and they contribute up to $68 \%$ of the total dietary intake in some countries. However, in the Czech Republic fatty fish contribute $20 \%$ at maximum (in the group of women aged 18-64 years). Although the Czech Nutrition Society (2012) recommends a weekly intake at least $400 \mathrm{~g}$ of fish and fish products [38], fish consumption is still low in the long term. Fish consumption was only $5.5 \mathrm{~kg}$ (raw) per capita per year in 2015 [39] i.e., about 100 g weekly. This is probably due to the Czech Republic's historical development, cultural traditions, and inland location. There are many attempts to increase fish consumption in the Czech population, for example, recommendations from professional authorities or media campaigns, but changing consumer habits is a long-term process. A wide range of fish and fish products is available on the Czech market, but it seems the specific fish characteristics (smell, relatively large numbers of small bones, higher price especially in sea fish etc.) could have a significant impact on the previously mentioned low consumption, mainly among children. Despite the described features, an increase in fish consumption in the Czech population is publicly supported because it is favorable not only for vitamin D but also for intake of other positive substances like omega 3 fatty acids. It should be mentioned that public health interventions to increase intake of vitamin D are not new. Children regularly received fish oil in schools during 1950s and early 1960s as a form of prevention of rickets.

Hen eggs, which are the major contributor to total vitamin D intake in the Czech Republic (up to $28 \%$ ), accounted for $20 \%$ at maximum in other compared countries. The reasons for the higher contribution in the Czech Republic are the flat fortification of feed for laying hens and a relatively high egg consumption rate.

There are several possibilities for how to improve vitamin D intake in a population. One of the most commonly used solutions is fortification of foods. For example, fortified fats are an important source of vitamin D in many countries (Denmark, Nordic countries, and the Czech Republic). However, the policy of vitamin D fortification is not harmonized across Europe. In the Czech Republic, mandatory food fortification applies only for nutrition for infants and young children. Other foods (margarines, milk, instant cocoa drinks etc.) are fortified voluntarily. At present, there are not a lot of vitamin D fortified products on the Czech market; those are mostly produced by global food companies. The introduction of mandatory fortification of certain products or voluntary fortification of a larger range of products (e.g., milk, dairy products, breakfast cereals, pasta etc.) could contribute substantially to higher vitamin D intake on a population-wide basis in the Czech Republic. However, the remaining issue is affordability of such products. Currently, vitamin D fortified milk is often twice as expensive as non-fortified milk, and therefore not cost-attractive for consumers.

Another possibility how to increase dietary intake is introduction of foods (mushrooms, yeast, pastry with yeast e.g., bread), which naturally contain the vitamin D precursor (ergosterol) and are treated with UVB light. Therefore, food producers could be encouraged to use UVB in food production. Since this measure is a relatively new method for the increasing vitamin D content in foods, such products are referred to as novel foods and their placement on the market is subject to special procedure.

Dietary supplements can be also a means to improve vitamin D intake. There are differences in the usage rate of dietary supplements across Europe. Higher consumption is typical for Nordic countries compared to the south of Europe and there are differences also between genders. The consumption is higher in women than in men [1]. In the Czech Republic there is compulsory supplementation of vitamin D in infants and small children in order to prevent of rickets. In other population groups it is voluntary. According to limited information from national survey (SISP04) we can assume that the frequency of days of consumption of dietary supplements containing vitamin D is about $6 \%$ in adult men and about $11 \%$ in adult women. 


\section{Conclusions}

The presented results indicate that in the Czech Republic there is a large percentage of people who do not meet the current recommended dietary intake for vitamin $\mathrm{D}$. The prevalence of inadequate dietary intake is estimated to be at least 95\% in the Czech population aged four and over. Small differences were observed in population groups, with the highest vitamin D intake being in adult men aged 18-64 years, and the lowest in children aged 4-6 years, girls aged 11-14 years, and women aged 15-17 years. Such findings should encourage public health authorities to support population interventions, consumer education, and possibly also implementation of regulatory measures for improving vitamin D intake, including not only voluntary food fortification.

Author Contributions: J.R. conceived the idea of assessment of vitamin D exposure in the Czech population, organized the research team, conducted the evaluation using the MCRA 8.2 system, and performed scientific supervision and manuscript revision. M.D. and J.B. carried out the preparation of analytical data for the evaluation of dietary exposure using the MCRA 8.2 system, supervised, and provided important information in the first version of the article. R.K. and J.N. carried out the chemical analysis of foods. I.R. organized the analytical work and performed supervision during the chemical analysis. S.B. processed and analyzed the chemical data on vitamin D, performed the preparation of analytical data for the evaluation using the MCRA 8.2 system, drafted the first version of this article, and incorporated all co-authors comments. All authors performed the final correction of this article. All authors read and approved the final version of this article.

Funding: This research received no external funding.

Acknowledgments: This research was supported by the Ministry of Health of the Czech Republic (conceptual development of research organizations, National Institute of Public Health, IN 75010330) and by the European Commission's Seventh Framework Programm (FP7/2012-2016) as a part of the TDS Exposure Project (grant agreement number 289108).

Conflicts of Interest: The authors declare no conflict of interest.

\section{References}

1. Spiro, A.; Buttriss, L. Vitamin D: An overview of vitamin D status and intake in Europe. Nutr. Bull. 2014, 39, 322-350. [CrossRef] [PubMed]

2. Pludowski, P.; Holick, M.F.; Pilz, F.; Wagner, C.L.; Hollis, B.W.; Grant, W.B.; Shoenfeld, Y.; Lerchbaum, E.; Llewellyn, D.J.; Kienreich, K.; Soni, M. Vitamin D effects on musculoskeletal health, immunity, autoimmunity, cardiovascular disease, cancer, fertility, pregnancy, dementia and mortality-A review of recent evidence. Autoimmun. Rev. 2013, 12, 976-989. [CrossRef] [PubMed]

3. European Food Safety Authority. Scientific opinion on dietary reference values for vitamin D. EFSA J. 2016, 14, 1-145. [CrossRef]

4. $\quad$ Finglas, P.M.; Roe, M.A.; Pinchen, H.M.; Berry, R.; Church, S.M.; Dodhia, S.K.; Farron-Wilson, M.; Swan, G. McCance and Widdowson's The Composition of Foods, Seventh Summary Edition; Royal Society of Chemistry: Cambridge, UK, 2015; p. 630, ISBN 978-1-84973-636-7.

5. Mattila, P.H.; Piironen, V.I.; Uusi-Rauva, E.J.; Koivistoinen, P.E. Vitamin D Contents in Edible Mushrooms. J. Agric. Food Chem. 1994, 42, 2449-2453. [CrossRef]

6. Institute of Medicine. Dietary Reference Intakes for Calcium and Vitamin D; The National Academies Press: Washington, DC, USA, 2011; pp. 1-1132. ISBN 978-0-309-16394-1.

7. Heaney, R.; Garland, C.; Baggerly, C.; French, C.; Gorham, E. Letter to Veugelers, P.J. and Ekwaru, J.P., A Statistical Error in the Estimation of the Recommended Dietary Allowance for Vitamin D. Nutrients 2014, 6, 4472-4475. [CrossRef]

8. D-A-CH Referenzwerte für die Nährstoffzufuhr, 2nd ed.; Deutsche Gesellschaft für Ernährung, Österreichische Gesellschaft für Ernährung, Schweizerische Gesellschaft für Ernährung: Bonn, Germany, 2015; ISBN 978-3-86528-148-7.

9. European Food Safety Authority/Food and Agriculture Organization of the United Nations/World Health Organisation. Towards a harmonised Total Diet Study approach: A guidance document. EFSA J. 2011, 9 , 1-66. [CrossRef] 
10. Brussaard, J.H.; Löwik, M.R.H.; Steingrimsdottir, L.; Møller, A.; Kearney, J.; De Henauw, S.; Becker, W. A European food consumption survey method-Conclusions and recommendations. Eur. J. Clin. Nutr. 2002, 56, 89-94. [CrossRef] [PubMed]

11. Black, A.E. Critical evaluation of energy intake using the Goldberg cut-off for energy intake: Basal metabolic rate. A practical guide to its calculation, use and limitations. Int. J. Obes. Relat. Metab. Disord. 2000, 24, 1119-1130. [CrossRef] [PubMed]

12. European Food safety Authority. The EFSA Comprehensive European Food Consumption Database. Available online: https:/ / www.efsa.europa.eu/en/food-consumption/comprehensive-database (accessed on 6 September 2018).

13. Merten, C.; Ferrari, P.; Bakker, M.; Boss, A.; Hearty, A.; Leclercq, C.; Lindtner, O.; Tlustos, C.; Verger, P.; Volatier, J.L.; Arcella, D. Methodological characteristics of the national dietary surveys carried out in the European Union as included in the European Food Safety Authority (EFSA) Comprehensive European Food Consumption Database. Food Addit. Contam. Part A Chem. Anal. Control. Expo. Risk Assess. 2011, 28, 975-995. [CrossRef] [PubMed]

14. Ruprich, J.; Dofkova, M.; Rehurkova, I.; Slamenikova, E.; Resova, D. Individual food consumption - the national study SISP04. CHFCH NIPH in Prague, 2006. Available online: http://czvp.szu.cz/ spotrebapotravin.htm (accessed on 6 June 2018).

15. Dodd, K.W.; Guenther, P.M.; Freedman, L.S.; Subar, A.F.; Kipnis, V.; Midthune, D.; Tooze, J.A.; Krebs-Smith, S.M. Statistical methods for estimating the usual intake of nutrients and foods: A review of the theory. J. Am. Diet. Assoc. 2006, 106, 1640-1650. [CrossRef] [PubMed]

16. European Food Safety Authority. Guidance on the EU Menu methodology. EFSA J. 2014, 12, 1-77. [CrossRef]

17. Environmental Health Monitoring System in the Czech Republic. Subsystem IV. Contaminants in Food Chains and Their Impact on Human Health in 2015. Expert Report, 2015. National Institute of Public Health: Prague: 2016. Available online: http:/ /www.szu.cz/uploads/documents/chzp/odborne_zpravy/OZ_15/ Odborna_dieta_2015.pdf (accessed on 6 June 2018).

18. Dofkova, M.; Karpisková, R.; Ostry, V.; Ruprich, J.; Rehurkova, I. Contaminants in food chains and their impact on human health, dietary exposure. In Environmental Health Monitoring System in the Czech Republic; Summary report 2016; Puklová, V., Ed.; National Institute of Public Health: Prague, Czech Republic, 2017; pp. 49-60. ISBN 978-80-7071-365-5.

19. Phillips, K.M.; Byrdwell, W.C.; Exler, J.; Harnly, J.M.; Holde, J.M.; Holick, M.F.; Hollis, B.W.; Horst, R.L.; Lemar, L.E.; Patterson, K.Y.; Tarrago-Trani, M.T.; Wolf, W.R. Development and validation of control materials for the measurement of vitamin D3 in selected US foods. J. Food Comp. 2008, 21, 527-534. [CrossRef]

20. MCRA (2016). MCRA 8.2 Reference Manual. Report Dec 2016. WUR/Biometris, FERA and RIVM. Available online: https: / / mcra.rivm.nl (accessed on 6 June 2018).

21. Van Rossum, C.T.M.; Fransen, H.P.; Verkaik-Kloosterman, J.; Buurma-Rethans, E.J.M.; Ocké, M.C. Dutch National Food Consumption Survey 2007-2010: Diet of Children and Adults Aged 7 to 69 Years. RIVM National Institute for Public Health and the Environment 2011, 148 pp. Available online: https:/ /www.rivm. $\mathrm{nl} /$ dsresource? objectid=3f528864-36cb-400b-8411-a47db4f99df4\&type=org\&disposition=inline (accessed on 6 June 2018).

22. Czech Statistical Office. Food Consumption-2014. Available online: https://www.czso.cz/csu/czso/foodconsumption-2014 (accessed on 14 September 2018).

23. European Food Safety Authority. The Food Classification and Description System FoodEx2 (Revision 2). Available online: https:/ / efsa.onlinelibrary.wiley.com/doi/epdf/10.2903/sp.efsa.2015.EN-804 (accessed on 12 September 2018).

24. European Food Safety Authority. Scientific Opinion on the Tolerable Upper Intake Level of vitamin D. EFSA J. 2012, 10, 1-45. [CrossRef]

25. Freisling, H.; Fahey, M.T.; Moskal, A.; Ocké, M.C.; Ferrari, P.; Jenab, M.; Norat, T.; Naska, A.; Welch, A.A.; Navarro, C.; et al. N. Region-specific nutrient intake patterns exhibit a geographical gradient within and between European countries. J. Nutr. 2010, 140, 1280-1286. [CrossRef] [PubMed]

26. Viñas, B.R.; Barba, R.L.; Ngo, J.; Gurinovic, M.; Novakovic, R.; Cavelaars, A.; de Groot, L.C.P.G.M.; van't Veer, P.; Matthys, C.; et al. Projected Prevalence of Inadequate Nutrient Intakes in Europe. Ann. Nutr. Metab. 2011, 59, 84-95. [CrossRef] [PubMed] 
27. Mensink, G.B.; Fletcher, R.; Gurinovic, M.; Huybrechts, I.; Lafay, L.; Serra-Majem, L.; Szponar, L.; Tetens, I.; Verkaik-Kloosterman, J.; Baka, A.; Stephen, A.M. Mapping low intake of micronutrients across Europe. Br. J. Nutr. 2013, 110, 755-773. [CrossRef] [PubMed]

28. Olza, J.; Aranceta-Bartrina, J.; González-Gross, M.; Ortega, R.M.; Serra-Majem, L.; Varela-Moreiras, G.; Gil, Á. Reported Dietary Intake, Disparity between the Reported Consumption and the Level Needed for Adequacy and Food Sources of Calcium, Phosphorus, Magnesium and Vitamin D in the Spanish Population: Findings from the ANIBES Study. Nutrients 2017, 9, 168. [CrossRef] [PubMed]

29. Moyersoen, I.; Devleesschauwer, B.; Dekkers, A.; de Ridder, K.; Tafforeau, J.; van Camp, J.; van Oyen, H.; Lachat, C. Intake of Fat-Soluble Vitamins in the Belgian Population: Adequacy and Contribution of Foods, Fortified Foods and Supplements. Nutrients 2017, 9, 860. [CrossRef] [PubMed]

30. National Institute of Public Health. Jsou české děti dostatečně zásobeny vitaminem D? Prague, 2017. Available online: http:/ / www.szu.cz/tema/zivotni-prostredi/vitamin-d-u-deti (accessed on 6 June 2018).

31. Bates, B.; Lennox, A.; Prentice, A.; Bates, C.; Page, P.; Nicholson, S.; Swan, G. National Diet and Nutrition Survey Results from Years 1, 2, 3 and 4 (Combined) of the Rolling Programme (2008/2009-2011/2012). A survey carried out on behalf of Public Health England and the Food Standards Agency 2014. Available online: https:/ / assets.publishing.service.gov.uk/government/uploads/system/uploads/attachment_data/ file/594361/NDNS_Y1_to_4_UK_report_full_text_revised_February_2017.pdf (accessed on 7 June 2018).

32. Irish Universities Nutrition Alliance (IUNA). National Adult Nutrition Survey. Summary Report March 2011. Available online: https:/ /irp-cdn.multiscreensite.com/46a7ad27/files/uploaded/The\%20National\% 20Adult\%20Nutrition\%20Survey\%20Summary\%20Report\%20March\%202011.pdf (accessed on 7 June 2018).

33. ANSES-French Agency for Food, Environmental and Occupational Health \& Safety. 2016. Vitamin D Presentation, Food Sources and Nutritional Needs. Available online: https:/ / www.anses.fr/en/content/ vitamin-d (accessed on 7 June 2018).

34. AESAN (Agencia Española de Seguridad Alimentaria y Nutrición). Evaluación nutricional de la dieta española. II Micronutrientes. Sobredatos de la Encuesta Nacional de Ingesta Dietética (ENIDE) 2011. Available online: http://www.laboratoriolcn.com/f/docs/Valoracion_nutricional_ENIDE_micronutrientes. pdf (accessed on 7 June 2018).

35. Pietinen, P.; Paturi, M.; Reinivuo, H.; Tapanainen, H.; Valsta, L.M. FINDIET 2007 Survey: Energy and nutrient intakes. Public Health Nutr. 2010, 13, 920-924. [CrossRef] [PubMed]

36. O'Mahony, L.; Stepien, M.; Gibney, M.J.; Nugent, A.P.; Brennan, L. The potential role of vitamin D enhanced foods in improving vitamin D status. Nutrients 2011, 3, 1023-1041. [CrossRef]

37. Lamberg-Allardt, C.; Brustad, M.; Meyer, H.E.; Steingrimsdottir, L. Vitamin D-A systematic literature review for the 5th edition of the Nordic Nutrition Recommendations. Food. Nutr. Res 2013, 57, 1-31. [CrossRef] [PubMed]

38. The Czech Society for Nutrition. Nutritional recommendations for the population of the Czech Republic-2012. Available online: http://www.vyzivaspol.cz/vyzivova-doporuceni-pro-obyvatelstvoceske-republiky / (accessed on 23 June 2018).

39. Czech Statistical Office. Food Consumption-2016. Available online: https://www.czso.cz/csu/czso/ spotreba-potravin-2016 (accessed on 7 June 2018).

(C) 2018 by the authors. Licensee MDPI, Basel, Switzerland. This article is an open access article distributed under the terms and conditions of the Creative Commons Attribution (CC BY) license (http:/ / creativecommons.org/licenses/by/4.0/). 